University of Nebraska - Lincoln

DigitalCommons@University of Nebraska - Lincoln

Agronomy \& Horticulture - Faculty Publications

Agronomy and Horticulture Department

4-25-2005

\title{
Remotely Measuring Chlorophyll Content in Corn Leaves with Differing Nitrogen Levels and Relative Water Content
}

\author{
Michael R. Schlemmer \\ University of Nebraska-Lincoln, michael.schlemmer@bayer.com \\ Dennis D. Francis \\ University of Nebraska-Lincoln, dfrancis1@unl.edu \\ J.F. Shanahan \\ University of Nebraska-Lincoln, jshanahan1@unl.edu \\ James S. Schepers \\ University of Nebraska-Lincoln, james.schepers@gmail.com
}

Follow this and additional works at: https://digitalcommons.unl.edu/agronomyfacpub

Part of the Plant Sciences Commons

Schlemmer, Michael R.; Francis, Dennis D.; Shanahan, J.F.; and Schepers, James S., "Remotely Measuring Chlorophyll Content in Corn Leaves with Differing Nitrogen Levels and Relative Water Content" (2005). Agronomy \& Horticulture -- Faculty Publications. 1.

https://digitalcommons.unl.edu/agronomyfacpub/1

This Article is brought to you for free and open access by the Agronomy and Horticulture Department at DigitalCommons@University of Nebraska - Lincoln. It has been accepted for inclusion in Agronomy \& Horticulture -Faculty Publications by an authorized administrator of DigitalCommons@University of Nebraska - Lincoln. 


\title{
Remotely Measuring Chlorophyll Content in Corn Leaves with Differing Nitrogen Levels and Relative Water Content
}

\author{
M. R. Schlemmer,* D. D. Francis, J. F. Shanahan, and J. S. Schepers
}

\begin{abstract}
Measuring a crop's physiological parameters provides information for interpreting its response to the environment. Remote sensing is quickly becoming recognized as a valuable tool that has the potential to assess a wide variety of physiological properties over a large area in a short amount of time. This study examined the relationship of corn (Zea mays L.) leaf spectral response to its chlorophyll content and relative water content. The effects of $\mathbf{N}$ stress and water stress were examined on each of these physiological parameters. Over the years, several spectral indices have been introduced for a wide variety of applications. A number of these indices were evaluated for their ability to predict the parameters in question. The normalized difference between the first derivatives at 525 and $570 \mathrm{~nm}$, as well as the wavelength location of the red edge, showed a strong association with chlorophyll content ( $r^{2}=0.81$ and 0.80 , respectively). Even stronger relationships to chlorophyll content were observed with the ratios of $600 / 680 \mathrm{~nm}\left(r^{2}=0.83\right)$ and $630 / 680 \mathrm{~nm}\left(r^{2}=0.83\right)$. Thus, our results suggest that spectral reflectance measurements hold promise for the assessment of some physiological parameters at the leaf level. Further investigation is needed to evaluate the effectiveness of such techniques at the canopy level.
\end{abstract}

$\mathrm{P}$ LANT NUTRIENTS and water are the most important, and readily manageable, variables for producing a profitable crop (Stevenson, 1982; Kozlowski, 1972). Nitrogen, because of its high demand in the plant and variability within the soil, is the most intensively managed plant nutrient in crop production. Stresses that involve deficiencies of $\mathrm{N}$ and water will adversely affect the amount of chlorophyll plants produce as well as cell turgidity.

A measurement commonly made by plant scientists is leaf chlorophyll content. This parameter is fundamental to understanding a plant's response to the environment in which it resides. Remotely sensed measurements of this parameter could provide information about the status of the plant without the use of destructive tissue sampling. Instruments have been developed that examine the reaction of light energy with leaf tissue for the purpose of providing rapid estimates of chlorophyll content. Markwell et al. (1995) reported a very strong relationship between the Minolta SPAD-502 chlorophyll meter readings and direct measurements of chlorophyll content in corn and soybean [Glycine max (L.) Merr.] leaves. Since chlorophyll content is usually strongly related to $\mathrm{N}$ concentration, these meters can be used as indicators of need for agricultural $\mathrm{N}$ application (Schepers et al., 1992; Blackmer and Schepers, 1995).

USDA-ARS, 119 Keim Hall, Univ. of Nebraska, Lincoln, NE 685830915. Received 11 May 2004. *Corresponding author (mschlemmer1@ unl.edu).

Published in Agron. J. 97:106-112 (2005).

(C) American Society of Agronomy

677 S. Segoe Rd., Madison, WI 53711 USA
A plant's photosynthetic potential is directly proportional to the quantity of chlorophyll present in the leaf tissue. Rapid estimates of photosynthetic potential can be important for studies of gas exchange and the $\mathrm{C}$ cycle. Carter (1998) showed that normalized difference vegetation index calculated with reflectance at $701 \pm 2$ $\mathrm{nm}$ and $820 \pm 2 \mathrm{~nm}$ or the simple ratio of the two is strongly associated with photosynthesis and stomatal conductance of a loblolly pine (Pinus taeda L.) canopy. Verma et al. (1993) examined the simple ratio of near infrared reflectance to red reflectance over unstressed prairie vegetation. The conclusion was that a nearly linear relationship exists between simple ratio and the derivatives of stomatal conductance and photosynthesis, with respect to photosynthetically active radiation, for unstressed canopies.

The objective of this study was to determine how corn leaf spectral reflectance is related to leaf tissue chlorophyll content and relative water content (RWC) under $\mathrm{N}$ and water-limiting conditions. An additional objective was to determine if the two different stress conditions would confound the estimation of either chlorophyll content or RWC.

\section{MATERIALS AND METHODS}

This experiment was conducted during the winter months of 1998-1999 under greenhouse conditions. Supplemental incandescent lighting was provided to extend the daylength to $14 \mathrm{~h}$. A day/night temperature of $29 / 18^{\circ} \mathrm{C}$ was maintained for the duration of the study. Seeds of the corn hybrid Pioneer brand $^{1}$ ' 3489 ' were planted on 11 Dec. 1998 in pots with a volume of $0.013 \mathrm{~m}^{3}$ containing a mixture of one-half sand and one-half potting soil. This was done to create a soil deficient in $\mathrm{N}$ while still allowing the soil to provide the plants with the required micronutrients. A solution of macronutrients, without $\mathrm{N}$, was added to each pot at appropriate levels to avoid any deficiencies of these nutrients. Since light environments may differ throughout the greenhouse bay, the pots were moved weekly to minimize any influence location within the greenhouse might have on plant growth. Treatments consisted of a factorial combination of three $\mathrm{N}$ levels $(56,112$, and $168 \mathrm{~kg} \mathrm{~N}^{-1}$ rate) and two water management strategies. The water management strategies consisted of two levels: adequate water level, which replenished daily use, and a water deficit level, which had water withheld $3 \mathrm{~d}$ before data collection. Four replications were established for this study.

Leaf physiological and optical properties were assessed on the plants at the V6 to V7 growth stage (Ritchie et al., 1997). The Minolta SPAD-502 chlorophyll meter ${ }^{1}$ was used, as per Markwell et al. (1995), to acquire a rapid estimate of leaf chlorophyll content. The measurements were taken on the upper-

${ }^{1}$ Mention of trade names or commercial products in this article is solely for the purpose of providing specific information and does not imply recommendation or endorsement by the USDA.

Abbreviations: RWC, relative water content. 
Table 1. Analysis of variance of $\mathbf{N}$ and water treatment effects on extracted leaf chlorophyll (chl), leaf chl by SPAD-502 meter, and leaf relative water content (RWC).

\begin{tabular}{lrccc}
\hline Source & df & Extracted chl & Chl by SPAD & RWC \\
\cline { 3 - 5 } & & & mean square & \\
$\mathbf{N}$ & 2 & $68139.2^{*}$ & $77613.5^{*}$ & $39.0 \mathrm{NS} \dagger$ \\
$\mathrm{H}_{2} \mathrm{O}$ & 1 & $102.7 \mathrm{NS}$ & $10285.4^{*}$ & $3821.6^{*}$ \\
$\mathrm{~N}^{*} \mathrm{H}_{2} \mathrm{O}$ & 2 & $1045.7 \mathrm{NS}$ & $1755.3 \mathrm{NS}$ & $38.4 \mathrm{NS}$ \\
Error & 18 & 2115.1 & 922.6 & 101.5 \\
\hline
\end{tabular}

* Significant at the 0.05 level.

$\uparrow$ NS, not significant.

most collared leaf halfway from the leaf base to the tip and halfway from the midrib to the leaf margin. Five measurements were taken per pot, one measurement on all of the five plants growing in each pot. The results were then averaged, resulting in a single value to represent that pot. Leaf optical properties were also acquired at the same location and in the same manner, as was the SPAD meter data. Adaxial leaf spectral reflectance was measured with the ASD Fieldspec FR spectroradiometer $^{1}$ (Analytical Spectral Devices, Boulder, CO) connected to a LI-COR integrating sphere ${ }^{1}$ (LI-COR Inc., Lincoln, NE). The ASD Fieldspec FR spectroradiometer records the reflectance from 350 to $2500 \mathrm{~nm}$ in 1-nm increments.

The plants were then sampled to determine leaf RWC and leaf chlorophyll content. This was accomplished by excising $1-\mathrm{cm}$ disks at the location remotely sensed data were collected on the uppermost collared leaf for each plant. The five disks from each pot were weighed immediately, providing a measure of fresh mass $\left(W_{\mathrm{f}}\right)$. After weighing, the disks were soaked in deionized water for $24 \mathrm{~h}$ and then weighed again to obtain a fully turgid mass $\left(W_{\mathrm{t}}\right)$. Finally, the leaf disks were dried at $85^{\circ} \mathrm{C}$ and weighed to get a dry mass $\left(W_{\mathrm{d}}\right)$. The leaf RWC is calculated as follows (Salisbury and Ross, 1992):

$$
\mathrm{RWC}=\left(W_{\mathrm{f}}-W_{\mathrm{d}}\right) /\left(W_{\mathrm{t}}-W_{\mathrm{d}}\right)
$$

An additional five leaf disks were then used for determination of actual leaf chlorophyll content by photometric methods as described by Porra et al. (1989). Chlorophyll was extracted from the leaf tissue using a buffered $80 \%$ aqueous acetone solution.

Analysis of variance was performed to determine treatment effects on measured physiological parameters (Table 1). Correlation and regression analyses were then performed to determine association among the measured physiological parameters and the leaf spectral reflectance and reflectance derivatives. The first derivatives were calculated using a nonparametric estimation of FFT (fast Fourier transform)-filtered

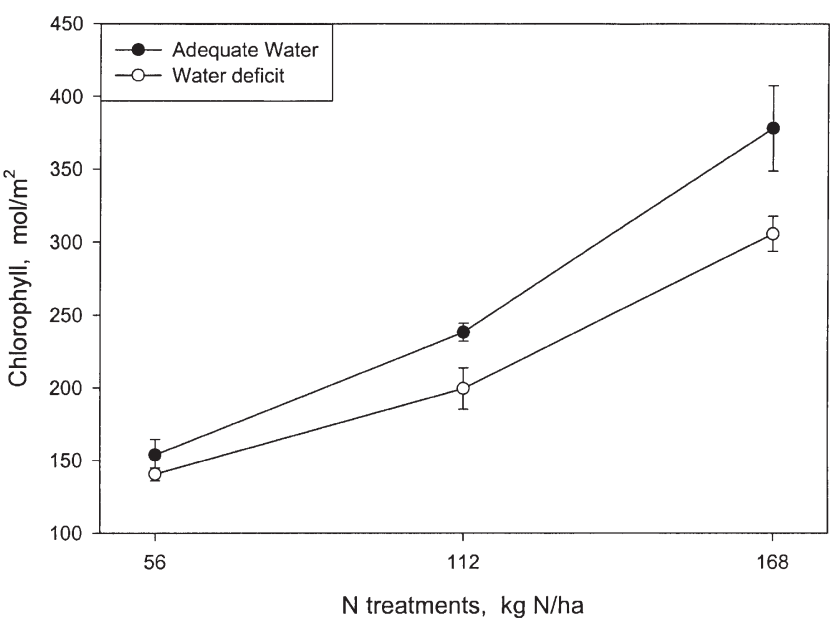

Fig. 1. Chlorophyll content by SPAD-502 meter for two water treatments.

smooth data fit to a B-spline (Table Curve 2D, Version 4, SPSS Inc., Chicago, IL; SPSS, 1996). ${ }^{1}$ This is necessary when using difficult-to-fit data, with the result being a smooth derivative. Regression analysis was then performed to determine the association of the spectral reflectance ratios listed in Table 2 to that of chlorophyll content and leaf RWC. Most reflectance ratios in Table 2 were selected from related literature. Two new ratios, orange/red chlorophyll absorption ratio (OCAR; 630/680 nm) and yellow/red chlorophyll absorption ratio (YCAR; 600/680 $\mathrm{nm}$ ), will be introduced because of their strong relationship to chlorophyll content.

\section{RESULTS AND DISCUSSION}

Leaf level measurements of actual extracted chlorophyll, chlorophyll content estimated by the SPAD-502 meter, and RWC were made on corn plants experiencing varying levels of $\mathrm{N}$ and water stress. The analysis of variance revealed that $\mathrm{N}$ and water treatment effects differed, depending on method of chlorophyll determination (Table 1). For example, extracted chlorophyll is significantly different for $\mathrm{N}$ treatments only while chlorophyll content determined by the SPAD-502 meter is significantly different for both $\mathrm{N}$ and water treatments. Using the SPAD-502 meter on plant tissue experiencing a water stress resulted in an underestimate of the chlorophyll content (Fig. 1). Results from the chloro-

Table 2. The spectral reflectance ratios to be evaluated and their definitions.

\section{Spectral}

reflectance ratios

\section{Definitions}

\begin{tabular}{|c|c|}
\hline $\mathbf{K}$ & the ratio of fluorescence peaks, $690 \mathrm{~nm} / 730 \mathrm{~nm}$, (Methy et al., 1994) \\
\hline PRI & physiological reflectance index, $(550 \mathrm{~nm}-530 \mathrm{~nm}) /(550 \mathrm{~nm}+530 \mathrm{~nm})$, (Gamon et al., 1992) \\
\hline WBI & water band index, $970 \mathrm{~nm} / 900 \mathrm{~nm}$, (Penuelas et al., 1994) \\
\hline NPCI & normalized pigments chlorophyll ratio index, $(680 \mathrm{~nm}-430 \mathrm{~nm}) /(680 \mathrm{~nm}+430 \mathrm{~nm})$, (Penuelas et al., 1994) \\
\hline GGFN & $\begin{array}{l}\text { difference between first derivative of } 525 \mathrm{~nm} \text { and } 570 \mathrm{~nm},(\mathrm{d525} \mathrm{nm}-\mathrm{d570} \mathrm{nm}) /(\mathrm{d525} \mathbf{\mathrm { nm }}+\mathbf{d 5 7 0} \mathrm{nm}) \text {, } \\
\text { (Penuelas et al., 1994) }\end{array}$ \\
\hline EGFN & 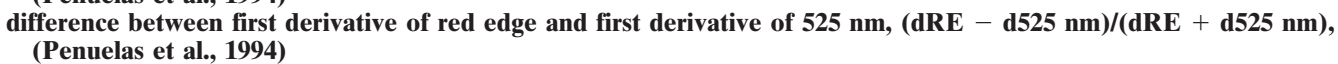 \\
\hline WRE & wavelength of red edge, (Penuelas et al., 1994) \\
\hline dRE & maximum of first derivative in the red edge, (Penuelas et al., 1994) \\
\hline Ratio1 & $701 \mathrm{~nm} / 595 \mathrm{~nm}$, (Carter, 1998) \\
\hline Ratio2 & $701 \mathrm{~nm} / 820 \mathrm{~nm}$, (Carter, 1998) \\
\hline Ratio3 & 740 nm/685 nm, (McMurtrey et al., 1994) \\
\hline Ratio4 & $525 \mathrm{~nm} / 685 \mathrm{~nm}$, (McMurtrey et al., 1994) \\
\hline Ratio5 & $440 \mathrm{~nm} / 685 \mathrm{~nm}$, (McMurtrey et al., 1994) \\
\hline OCAR & orange/red chlorophyll absorption ratio, $630 \mathrm{~nm} / 680 \mathrm{~nm}$ \\
\hline YCAR & yellow/red chlorophyll absorption ratio, $600 \mathrm{~nm} / 680 \mathrm{~nm}$ \\
\hline
\end{tabular}




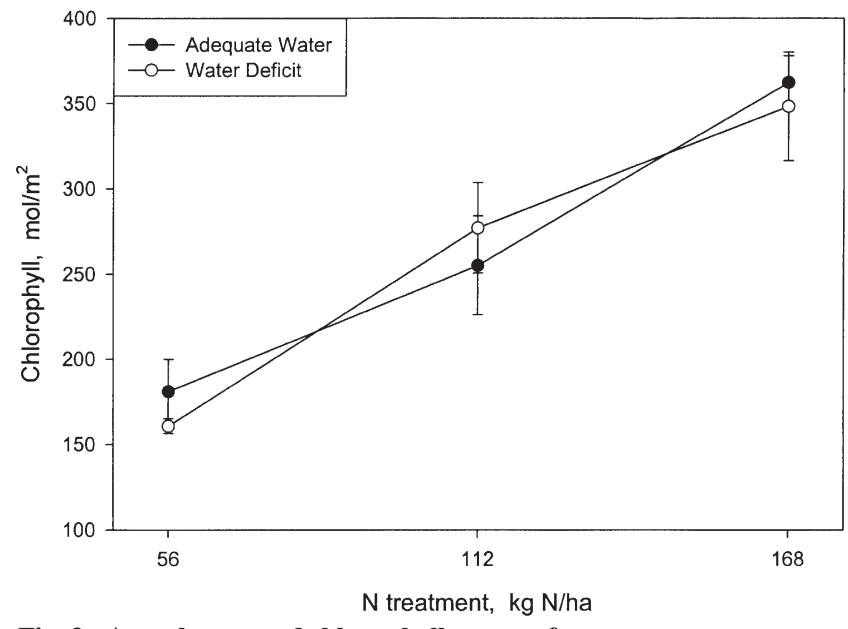

Fig. 2. Actual extracted chlorophyll content for two water treatments.

phyll extraction procedure (Fig. 2) indicate water stress did not affect chlorophyll content. When adequate water is present, the SPAD-502 meter provides results similar to the extraction method. Other studies have shown a similar response of water stress on SPAD-502 meter readings. Schepers et al. (1996), for example, noted that water stress was responsible for a weak association with leaf $\mathrm{N}$ concentrations. Figure 2 indicates that $\mathrm{N}$ is the only treatment in this experiment that influences the actual extracted chlorophyll content. This was anticipated since reduced cell turgor has no immediate impact on chlorophyll content but does impact the transmittance of near infrared energy through the leaf tissue. Transmittance of near infrared energy is influenced by the occurrence of intercellular air spaces present in leaf tissue. These variations of intercellular air spaces are directly influenced by the plant's water status. Output from the Minolta SPAD-502 chlorophyll meter is a function of leaf transmittance in the red and near infrared portion of the electromagnetic spectrum (650 and 940 $\mathrm{nm}$ ). Since the SPAD-502 meter underestimates chlorophyll content in water-stressed environments, subsequent discussion of chlorophyll content will be confined to the results of the direct measurement of chlorophyll by extraction.

As expected, leaf RWC was significantly different with the water treatment only (Table 1; Fig. 3). It ranged from a high of approximately $90 \%$ for well-watered treatments to a low of $65 \%$ for low-water treatments, averaged across all $\mathrm{N}$ rates.

Correlation analysis provided insight into the relationship between the spectral response of each wavelength and the physiological parameters of interest. By visually inspecting the spectral reflectance curves of Fig. 4, it becomes very apparent that the treatments in this study produced effects in the wavelength regions of 525 to $680 \mathrm{~nm}$ and 740 to $800 \mathrm{~nm}$. Water treatments appear to separate in the $740-$ to $800-\mathrm{nm}$ region. This region of the spectrum is strongly influenced by leaf cell structure. The varying water levels imposed on the plants in this study will alter the cell turgidity enough to create a change in leaf cell structure. This change in leaf structure will affect how energy from the near

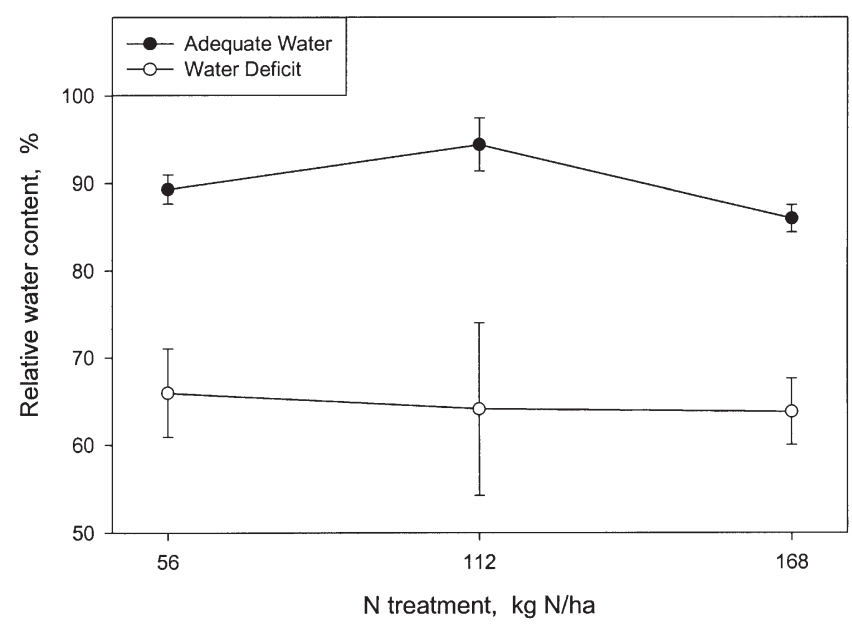

Fig. 3. Relative water content for two water treatments.

infrared portion of the spectrum will be absorbed, transmitted, or reflected. The water deficit treatments had higher reflectance than those of the adequate water treatments in this spectral region while $\mathrm{N}$ treatments seem to have little impact. Since N availability affects chlorophyll content, and chlorophyll in turn affects leaf greenness, one would expect the reflectance magnitudes within the region 525 to $680 \mathrm{~nm}$ to change as a result of the $\mathrm{N}$ treatment. However, $\mathrm{N}$ treatment is not the only effect responsible for the separation. Water stress seems to have a compounding effect. For example, leaf reflectivity increases with an increase in $\mathrm{N}$ stress as well as with increased water stress (Fig. 4). The additional increase in reflectance serves as a plant defense mechanism under water-limiting conditions by reducing energy absorption and minimizing increases in plant temperature. This interaction may explain the low relationship between the commonly used vegetation ratios and chlorophyll content under water stress conditions. Further examination of the spectral curves in Fig. 4 illustrates that the shape of the curves may be more a function of $\mathrm{N}$ than water. The slope from 600 to $680 \mathrm{~nm}$ appears to vary with $\mathrm{N}$ treatments only. This observation led to the creation of the final two ratios in Table 2 identified as OCAR and YCAR and further examination into derivative analysis of the spectral curve.

Figure 5 shows the result of correlation analysis between the spectral reflectance at each wavelength and the physiological parameters of interest. Also illustrated in Fig. 5 is the strong inverse correlation that exists between chlorophyll content and reflectance in two wavelength regions, 525 to $630 \mathrm{~nm}$ and a narrow region around $705 \mathrm{~nm}$. The 525 - to $630-\mathrm{nm}$ region is responsible for defining the plant's green color. As chlorophyll content decreases, reflectance in this region increases (the leaf will turn from green to a more yellowish green color). The wavelength region around $705 \mathrm{~nm}$ is commonly known as the red edge. The red edge is defined by the location of the inflection point in the transition region from red to near infrared. The location of the red edge is a function of chlorophyll absorption. As stress occurs, the red edge will shift to lower wavelengths. Healthy plants absorb more energy in wave- 


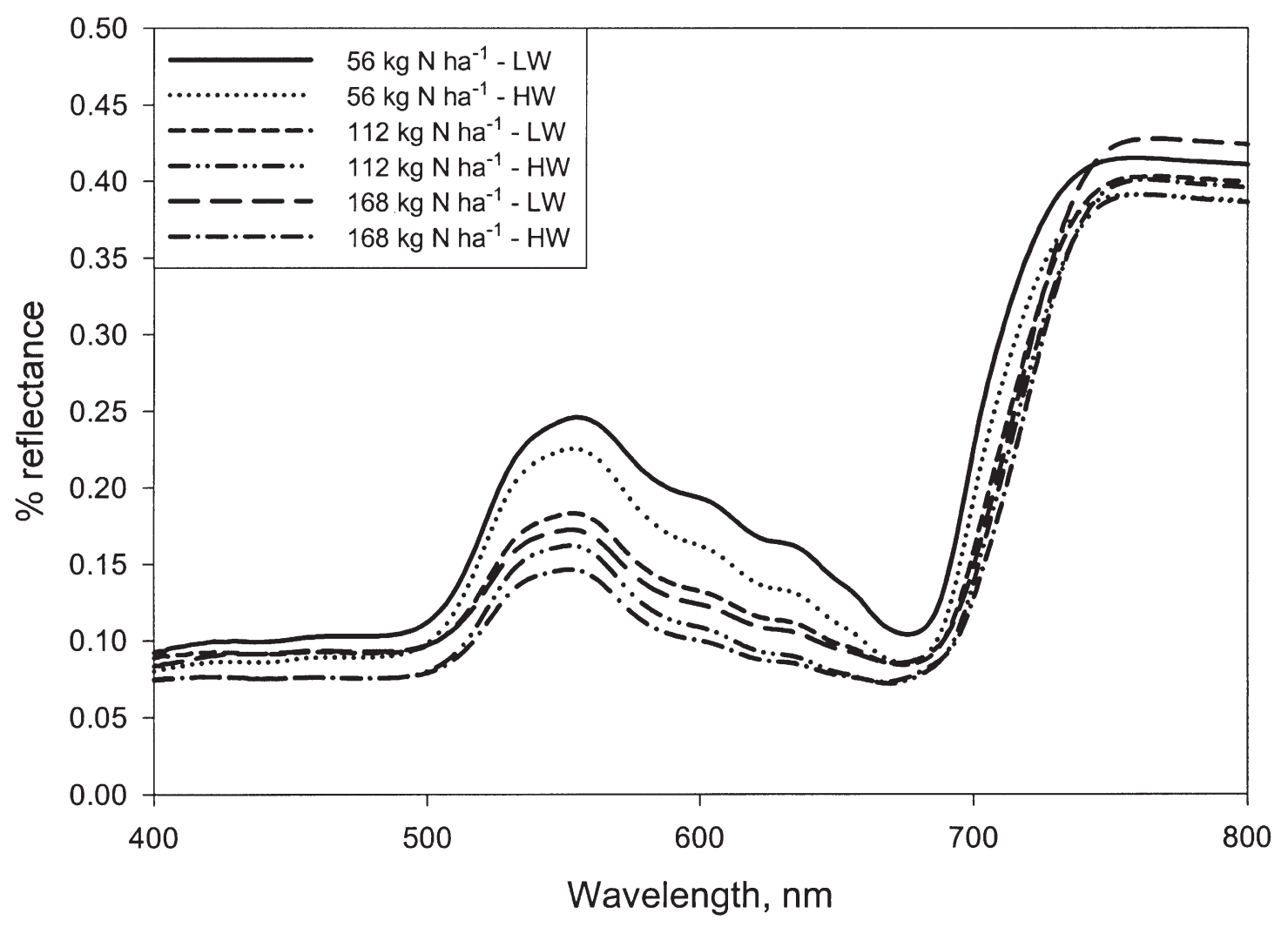

Fig. 4. Adaxial reflectance for all treatment combinations $(\mathrm{LW}=$ water deficit, $\mathrm{HW}=$ adequate water).

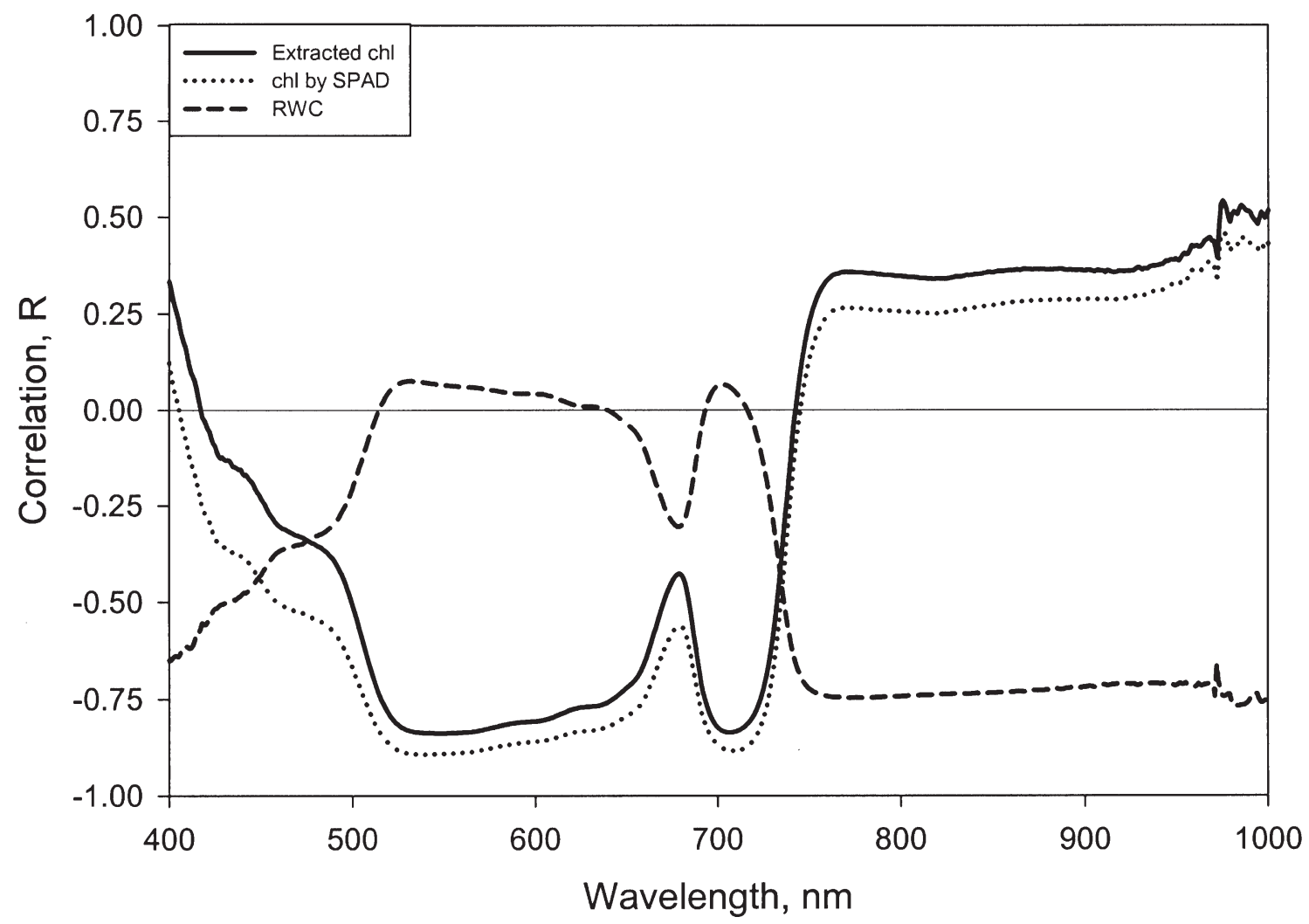

Fig. 5. Correlation of adaxial reflectance to physiological parameters. chl, chlorophyll; RWC, relative water content. 


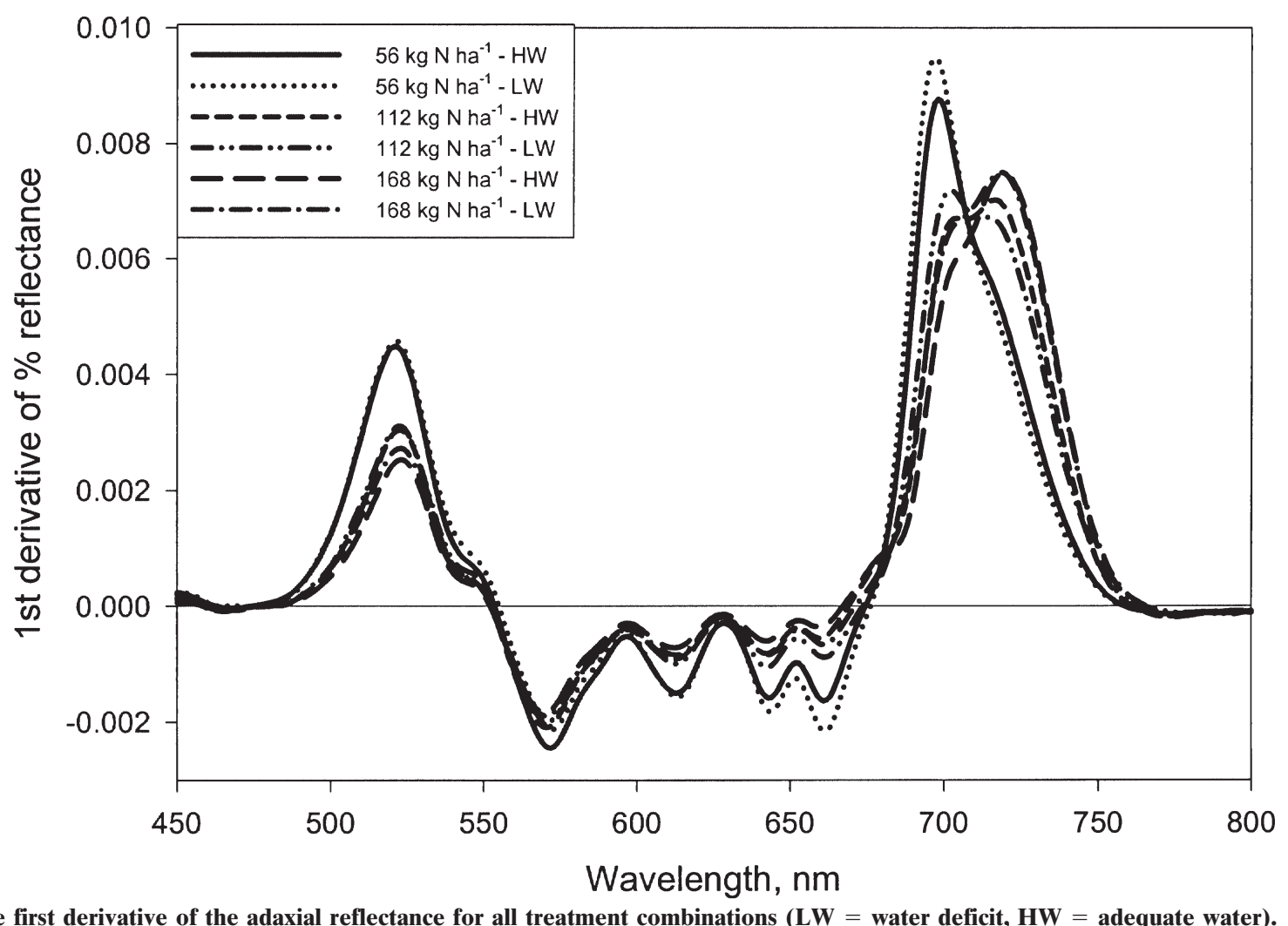

Fig. 6. The first derivative of the adaxial reflectance for all treatment combinations $(\mathrm{LW}=$ water deficit, $\mathrm{HW}=$ adequate water).

lengths beyond $680 \mathrm{~nm}$, thereby extending the red edge to higher wavelengths. Monitoring the location of this inflection point can provide a measure of stress that results in chlorophyll degradation. Finally, leaf RWC showed a strong inverse relationship to reflectance at wavelengths greater than $750 \mathrm{~nm}$ (Fig. 5). Cell structure impacts the way energy in the near infrared region interacts with the leaf. Reflected or scattered energy increases as cell turgor declines.

The first derivative of the reflectance curves can provide information about rate of change along the curve and at what wavelength these changes occur. Such insight is not apparent with simple reflectance curves (Fig. 6). The spikes in Fig. 6 identify the location of the inflection points from the reflectance curves and indicate the magnitude and direction for the rate of change at those inflection points. The magnitude of the spikes at 525, 575, 610, and 640 to $660 \mathrm{~nm}$ appears to show a strong relationship to the $\mathrm{N}$ treatments. The location of the spikes between 695 and $730 \mathrm{~nm}$ identifies the inflection points of the red-edge region. At the lowest $\mathrm{N}$ treatment, the red edge occurs near $695 \mathrm{~nm}$ for both water treatments. At the higher $\mathrm{N}$ treatment, the red edge occurs near $730 \mathrm{~nm}$ for both water treatments. It would appear that the position of the red edge is a function of $\mathrm{N}$, not water status.

The correlation analysis of Fig. 7 indicates strong relationships exist with the magnitudes of the first derivative and chlorophyll content. The RWC has a very weak relationship with the first derivative. Figure 7 shows strong negative correlations with chlorophyll content exist at 500 to $525 \mathrm{~nm}$ and at the leading edge of the red- edge region ( 695 to $700 \mathrm{~nm}$ ). Strong positive correlations exist at $575 \mathrm{~nm}, 610 \mathrm{~nm}, 630$ to $670 \mathrm{~nm}$, and at the trailing edge of the red-edge region $(710$ to $750 \mathrm{~nm})$. This indicates that changes in the shape of the reflectance curves are largely a function of the leaf chlorophyll content. These regions of change and the magnitude of change have shown to be good predictors of chlorophyll content (Penuelas et al., 1994). The correlation results for both reflectance and the first derivative to that of chlorophyll content support the use of a few of the ratios found in Table 2 such as GGFN, WRE, Ratio1, OCAR, and YCAR.

The ratios of Table 2 were examined because of their reported success for correlating well to chlorophyll content and/or RWC. Table 3 shows how well those ratios related to the physiological parameter measured in this study. The ratios GGFN and WRE show a strong association with the extracted chlorophyll content $\left(r^{2}=0.81\right.$ and 0.80 , respectively). The ratio GGFN is the normalized difference between the first derivative at 525 and $570 \mathrm{~nm}$. Both of these locations are inflection points for the reflectance curves. The first derivative at $570 \mathrm{~nm}$ is negative while the first derivative at $525 \mathrm{~nm}$ is positive. Both appear to be a function of the $\mathrm{N}$ treatment and are strongly correlated to chlorophyll content, one being positively correlated while the other is negatively correlated. This provides the strong correlation the normalized difference ratio has with the chlorophyll content at these wavelengths. Wavelength location of the red edge (WRE) can be easily identified by locating the peak of the first derivative curve within the region 695 to $730 \mathrm{~nm}$ (Fig. 6). These peak locations appear to be 


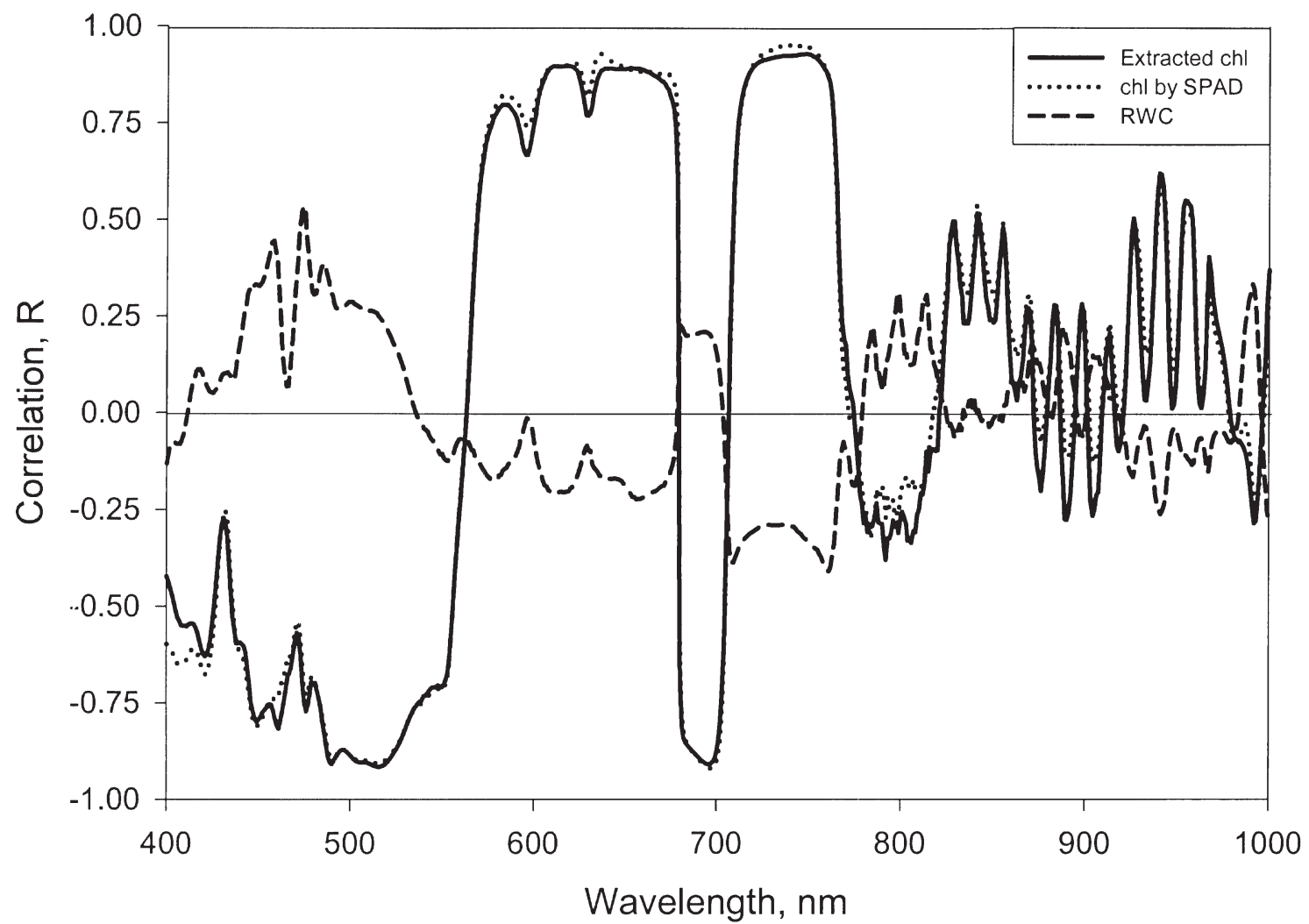

Fig. 7. Correlation of physiological parameters to the first derivative of the adaxial reflectance. chl, chlorophyll; RWC, relative water content.

strongly dependant on the $\mathrm{N}$ treatment with no impact from the water treatments, and therefore a strong relationship to chlorophyll content exists. Chlorophyll absorbs strongly in and around the 670-nm region. When chlorophyll content increases, the region of absorption begins to spread out, moving the red edge toward 730 $\mathrm{nm}$. Concurrently, there is an increase in absorption back to $600 \mathrm{~nm}$, which decreases the slope of the line between 600 and $680 \mathrm{~nm}$ (Fig. 4). The ratios OCAR and YCAR can be used to describe this slope by calculating ratios using points along this line. Both ratios show a very strong association with chlorophyll content $\left(r^{2}=\right.$ 0.83 ). All ratios were examined for relationship to leaf RWC, none of which performed well.

\section{CONCLUSIONS}

Results of this study indicate that spectral reflectance appears to have promise for estimating certain physiological parameters at the leaf level. Chlorophyll content shows a stronger association with the spectral ratios examined than did leaf RWC. Chlorophyll content also had the strongest correlation within various regions of the spectral reflectance curves and the first derivatives of those reflectance curves. This is the result of differing responses to $\mathrm{N}$ and water on the physiological parameters examined. Leaf available $\mathrm{N}$ content has a direct and proportional impact on leaf chlorophyll content compared with a short-duration acute water stress, which will have little or no affect. Nutrients or herbicides that affect the chlorophyll content of the leaf should experience a strong relationship to the same ratios, regions of the spectral reflectance curves, and the first derivatives of those reflectance curves, as noted in this study. However, water stress will affect plants differently. An acute water stress will not have an immediate impact on chlorophyll content but will affect the leaf's spectral reflectance. This results in a diminished relationship between spectral reflectance and the physiological parameters of interest.

Results of this study provide information at the leaf level. Further research needs to be conducted to evaluate the relationships of visible and near infrared reflectance with the physiological parameters measured at the whole canopy level.

Table 3. Regression analysis, comparing reflectance ratios to the physiological parameters.

\begin{tabular}{|c|c|c|}
\hline $\begin{array}{l}\text { Spectral } \\
\text { reflectance ratios }\end{array}$ & $\begin{array}{c}\text { Chlorophyll } \\
\text { extraction }\end{array}$ & $\mathbf{R W C} \dagger$ \\
\hline & & \\
\hline K & 0.45 & NS \\
\hline PRI & $\mathbf{N S} \ddagger$ & NS \\
\hline WBI & 0.19 & NS \\
\hline NPCI & 0.44 & NS \\
\hline GGFN & 0.81 & NS \\
\hline EGFN & 0.56 & NS \\
\hline WRE & 0.80 & NS \\
\hline dRE & 0.67 & NS \\
\hline Ratio1 & 0.27 & NS \\
\hline Ratio2 & 0.77 & NS \\
\hline Ratio3 & 0.31 & NS \\
\hline Ratio4 & 0.60 & 0.19 \\
\hline Ratio5 & 0.59 & 0.15 \\
\hline OCAR & 0.83 & NS \\
\hline YCAR & 0.83 & NS \\
\hline
\end{tabular}

$\dagger \mathbf{R W C}$, relative water content.

† NS, not significant. 


\section{REFERENCES}

Blackmer, T.M., and J.S. Schepers. 1995. Use of a chlorophyll meter to monitor nitrogen status and schedule fertigation for corn. J. Prod. Agric. 8:56-60.

Carter, C.A. 1998. Reflectance wavebands and indices for remote estimation of photosynthesis and stomatal conductance of pine canopies. Remote Sens. Environ. 63:61-72.

Gamon, J.A., J. Penuelas, and C.B. Field. 1992. A narrow-waveband spectral index that tracks diurnal changes in photosynthetic efficiency. Remote Sens. Environ. 41:35-44.

Kozlowski, T.T. (ed.) 1972. Water deficits and plant growth. Academic Press, New York.

Markwell, J., J.C. Osterman, and J.L. Mitchell. 1995. Calibration of the Minolta SPAD-502 leaf chlorophyll meter. Photosynth. Res. 46:467-472.

McMurtrey, J.E., III, E.W. Chappelle, M.S. Kim, J.J. Meisinger, and L.A. Corp. 1994. Distinguishing nitrogen fertilization levels in field corn (Zea mays L.) with actively induced fluorescence and passive reflectance measurements. Remote Sens. Environ. 47:36-44.

Methy, M., A. Olioso, and L. Trabaud. 1994. Chlorophyll fluorescence as a tool for management of plant resources. Remote Sens. Environ. 47:2-9.

Penuelas, J., J.A. Gamon, A.L. Fredeen, J. Merino, and C.B. Field. 1994. Reflectance indices associated with physiological changes in nitrogen- and water-limited sunflower leaves. Remote Sens. Environ. 48:135-146.
Porra, R.J., W.A. Thompson, and P.E. Kriedemann. 1989. Determination of accurate extinction coefficients and simultaneous equations for assaying chlorophylls $a$ and $b$ extracted with four different solvents: Verification of the concentration of chlorophyll standards by atomic absorption spectroscopy. Biochim. Biophys. Acta 975: 384-394.

Ritchie, S.W., J.J. Hanaway, and G.O. Benson. 1997. How a corn plant develops. Spec. Rep. 48. Iowa State Univ. Coop. Ext. Serv., Ames.

Salisbury, F.B., and C.W. Ross. 1992. Plant physiology. 4th ed. Wadsworth Publ. Co., Belmont, CA.

Schepers, J.S., T.M. Blackmer, W.W. Wilhelm, and M. Resende. 1996. Transmittance and reflectance measurements of corn leaves from plants with different nitrogen and water supply. J. Plant Physiol. 148:523-529.

Schepers, J.S., D.D. Francis, M. Vigil, F.E. Below. 1992. Comparison of corn leaf nitrogen concentration and chlorophyll meter readings. Commun. Soil Sci. Plant Anal. 23(17-20):2173-2187.

SPSS. 1996. Table Curve 2D for Windows. Version 4. SPSS Inc., Chicago, IL.

Stevenson, F.J. (ed.) 1982. Nitrogen in agricultural soils. Agron. Monogr. 22. ASA, CSSA, and SSSA, Madison, WI.

Verma, S.B., P.J. Sellers, C.L. Walthall, F.G. Hall, J. Kim, and S.J. Goetz. 1993. Photosynthesis and stomatal conductance related to reflectance on the canopy scale. Remote Sens. Environ. 44:103-116.

Yoder, B.J., and R.E. Pettigrew-Crosby. 1995. Predicting nitrogen and chlorophyll content and concentrations from reflectance spectra (400-2500 nm) at leaf and canopy scales. Remote Sens. Environ. 53:199-211. 